\title{
The analysis of farmers' access mechanism and social network in community-based forest management programs in Garut Regency, West Java Province Indonesia
}

\author{
Ahmad Choibar Tridakusumah ${ }^{*}$, Dika Supyandi, Mahra Arari, Ganjar Kurnia, and Yayat \\ Sukayat \\ Universitas Padjadjaran, Faculty of Agriculture, Indonesia
}

\begin{abstract}
This study aims to analyze access mechanisms and social networks formed in community-based forest management programs. This study uses a qualitative approach through access and social network analysis based on the results of in-depth interviews with 23 farmers as $\mathrm{s}$ who are members of the Kramatjaya forest farmer group in Cisurupan District, Garut Regency, West Java, Indonesia, which were conducted from September 2020 to February 2021. the stage of maintaining access through efforts to increase and maintain types of access to capital, technology, knowledge, markets and social relations. This study also shows the form of the Radial Personal Network which shows the form of a personal network that is widespread, large, and open to outside information so that it is one way to improve the welfare of farmers.
\end{abstract}

\section{Introduction}

Forests on the island of Java Indonesia, are surrounded by $\pm 6,807$ villages or $30 \%$ of the total population, Indonesia. As many as $60 \%$ of the population are farmers who depend on agriculture and are classified as poor [1]. This is also related to the issue of community access to forests to meet their livelihoods. Another issue also shows that farmers located at the forest margins often do not hold formal titles. Without land titles, these farmers are less able to intensify and more likely to expand into the surrounding forest land to increase agricultural output [2]. The community-based forest management program is one of the efforts to overcome this problem, where farmers join a forest farmer group. The program has been implemented in state forest in Java since 2001 [3]. The program has been developed to alleviate rural poverty and deforestation, but after two decades, that the program did not achieve its objectives [4].

The Kramatjaya Forest Farmers Group (FFG) is one of the groups participating in the Community-based forest management program, precisely in Garut Regency, West Java Province as cases in this research. In 2007, Community Forest Management program in Cisurupan District Garut Regency was launched, that opened up opportunities for forest

* Corresponding author: ahmad.choibar@unpad.ac.id 
village communities to be actively involved in forest management [6]. The active involvement of farmers around the forest in the research location, has been started before the program started, the establishment of cooperation between Perhutani and farmers who are members of the Kramatjaya Forest Farmer Groups. During the period 1997 until now, the system has been running in accordance with the objectives of empowering forest village communities, that in research locations sustainable forest resource management and improving the welfare of forest village communities

This study seeks to examine further, the problem of access of farmers who are members of the Kramatjaya FFG to forest resources, along with farmers' access to other resources using an access theory approach, which is an analysis of ways that allow a person to benefit from things [5]. Access analysis is used to explain why an actor has one ability to benefit from a resource, while another does not. This capability is a set of forces that enable actors to improve, control, and maintain access to resources, more specifically land [5]. The study of access means the ability to make use of something. The focus of attention on access analysis in this study is to further examine the mechanisms and types of access of actors who benefit from state forest areas. Therefore, access is the whole meaning that allows actors to be able to benefit from land and access that is formed and gets the influence of technology, capital, markets, knowledge, authority, identity and relations [1]. Therefore, the access analysis examines the actors who really benefit from state forest lands that are used by farmers. Empirically, access analysis seeks to reveal who benefits and through certain ways in a social network formed by both individuals and communities.

In general, social network analysis (SNA) is the mapping and measuring of relationships and flows between people, groups, organisations, computers or other information/knowledge processing entities [3]. Social Network Analysis is also a method for visualizing our people and connection power, leading us to identify how we can best interact to share knowledge. SNA is a method used to analyze a social relationship by looking at measures such as cohesion, density and dimensions of individuals or actors in a network [4]. This analysis is useful for identifying and examining the information transformation process between each actor [5], so that it can be seen which actors are key players in a network. This network of actors and access in the context of this research is of course very closely related to farmer institutions that are formed in utilizing forest land for community welfare.

Social networks play a significant role for the spread of information about commodities [7]. Strengthening social networks can also open opportunities to increase and maintain access to financial aspects [8], market and technology [9], and also to increase access to knowledge and skills [10]. Farmers as a collective force [11] in community forest management, can improve and maintain various accesses that play a role in improving the welfare of farmers. Farmers around the forest in the research location, continuously trying to improve, control and maintain access to state-owned forestry land that is used as agricultural land. This is also followed by efforts to strengthen and enhance internal and external social networks. Based on that, this study aims to analyze the mechanisms and types of access that work in it and further examine the social networks that are formed in participatory forest management.

\section{Methods}

\subsection{Site selection}

Cisurupan is a sub-district in Garut Regency, West Java Province, Indonesia. This district is about $22 \mathrm{~km}$ from the capital city of Garut Regency. The center of government is in 
Balewangi Village. Here there is a very famous tourist attraction in West Java, namely the Mount Papandayan crater. Cisurupan sub-district consists of 17 villages (Figure 1), and most of the villages are located at an altitude of 1,000 -1,300 above sea level. Majority of the population work as farmers, and a small proportion work in the livestock, fisheries and tourism sectors.

At this location there are Kramatjaya forest farmer groups that participating in the Community Based forest management program, within which this research was designed and conducted. The community has been involved in many development programs since the early 2000s. The farmers in Cisurupan Garut are a homogeneous community with equal power relations and internal social networks and already formed several hundred years ago which are bound to each other by strong community leader.

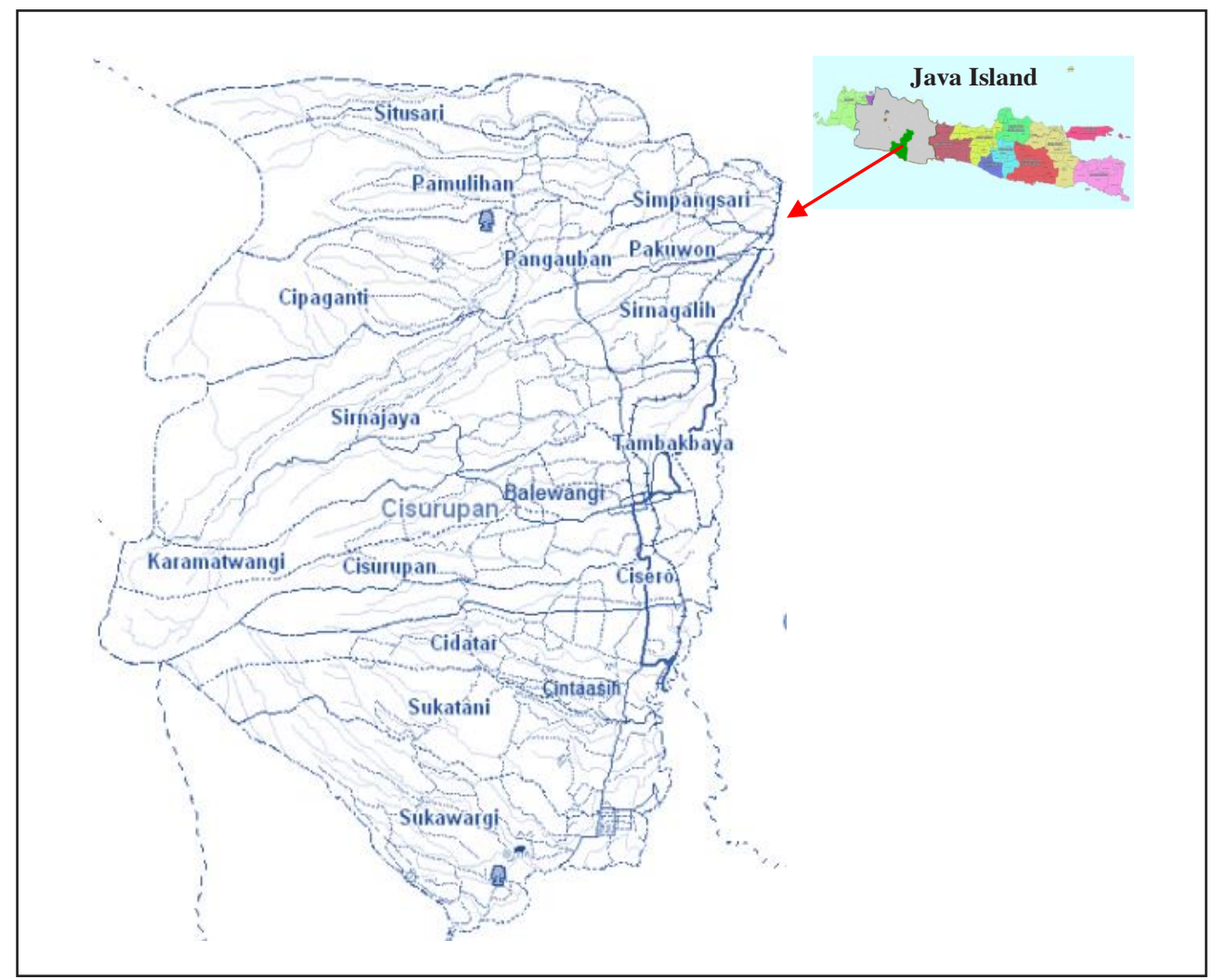

Fig. 1. Cisurupan District Garut Regency West Java Province

The participants in this study were 23 farmers who are members of FFG Kramatjaya. These farmers are active members and are cultivators in State-owned forestry lands with an average land tenure of less than 1 hectare used for coffee and vegetables. Table 1 shows that demographically, most of the participating farmers $(30.43 \%)$ are young and have primary school education $(69.57 \%)$. Besides that, it is quite interesting that most of the farmers $(39.13 \%)$ are young farmers have farming experience between 11 to 20 years. as explained by the head of the farmer group that :

"For human resources in Karamatwangi Village, it's not difficult, actually, we have a lot of potential for good human resources. Moreover, the youth who are now also farming, there is a youth farmer here, a small group formed to 
improve the quality of natural resources so that not only parents but also the youth also come to the garden to cultivate their farm."

Tabel 1. Demographics of research participants

\begin{tabular}{|c|c|c|l|l|r|r|l|l|r|r|}
\hline Ages & $\mathbf{f}$ & $\mathbf{\%}$ & & Education & \multicolumn{1}{|c|}{$\mathbf{f}$} & \multicolumn{1}{|c|}{} & & farming experience & \multicolumn{1}{|c|}{ f } & \multicolumn{1}{|c|}{} \\
\hline $31-40$ & 7 & 30.43 & & no school & 2 & 8.70 & & $<10$ & 4 & 17.39 \\
\hline $41-50$ & 4 & 17.39 & & primary school & 16 & 69.57 & & $11-20$ & 9 & 39.13 \\
\hline $51-60$ & 6 & 26.09 & & Junior high school & 2 & 8.70 & & $21-30$ & 2 & 8.70 \\
\hline$\geqq 61$ & 6 & 26.09 & & senior high school & 3 & 13.04 & & $31-40$ & 5 & 21.74 \\
\hline & & & & & & & & $41-50$ & 2 & 8.70 \\
\hline & & & & & & & & $>50$ & 1 & 4.35 \\
\hline SUM & $\mathbf{2 3}$ & $\mathbf{1 0 0}$ & & $\mathbf{2 3}$ & $\mathbf{1 0 0}$ & & & $\mathbf{2 3}$ & $\mathbf{1 0 0}$ \\
\hline
\end{tabular}

\subsection{Research approach}

In-depth interview technique was used in this study on 23 farmers. The research s are male and female heads of household who since 1997 have used state forest land to plant arabica coffee which is considered a conservation crop as well as improving their welfare. In addition, in-depth interviews with key informants and informal discussions with facilitators, village heads and community leaders were also conducted. Key informants were identified through focus group discussions and interviews with village government officials, extension workers and project managers, representatives from the forestry service and representatives from the agriculture office.

Interviews with farmers were intended to understand (1) the mechanism of access as well as the types of farmers' access to state-owned forestry lands, and (2) the relationship between individuals and households with internal and external social networks. The questions used for interviews are semi-structured. The first part consists of a list of questions regarding access mechanisms and types of farmer access. The second part is a questionnaire that focuses on the network of relationships used by farmers for internal and external affairs, both with fellow members within the group and external entities outside the group, such as with the government, investors, traders and resellers. Another set of questions is used to identify formal and informal leaders or fellow members, who play a role in influencing collective decisions. The participating farmers were also asked to state their relationship with the people they chose to know the strength and weakness of the bonds between them.

\subsection{Data analysis}

The data analysis used both access mechanism analysis and social network analysis. Firstly, to analyze the mechanisms and types of access by using a descriptive-qualitative analysis method, namely to examine in depth the types of access that can be utilized by the community and structural and relational-based access mechanisms and access types [12, 13]. Secondly, to describe the social networks that are formed, was use Social Network Analysis (SNA) which examines the structure of relationships that link individuals or other social units as well as dependencies in behavior or attitudes related to the composition of social relationships. The relationship is described by nodes and ties or also called edges, links or connections.

Nodes are actors in a network, while ties are lines that connect one node to another [14]. The measure of the proximity of one node to another in network analysis is centrality. Centrality is divided into several parts but in this study using three centralities, namely: 
Degree Centrality, Closeness centrality, Betweenness Centrality [15]. The data were analyzed using Pajek software Version 5.13 [3].

\section{Result and Discussion}

\subsection{Analysis of mechanisms and types of access}

A description of the access mechanism obtained by member farmers is categorized as a structural and relational-based access mechanism. The reason is that community access to state forest land is obtained through consultation with the government and the management of Mount Papandayan tourism. Based on the method of obtaining it, the access mechanism cannot be categorized as a rights-based access mechanism because it is not accommodated by applicable law. However, access mechanisms are formed and obtained based on relationships and trust. These relationships and trusts are influenced by various interests and depend on agreements and agreements resulting from deliberation between the community and the government through community based forest management programs. The types of access used by farmers consist of access to technology, labor, social identity, social relations, and authority (Table 2).

Table 2. The Forest Farmer Group Access Mechanism and Types

\begin{tabular}{|c|c|c|}
\hline Gaining Access Strategy & Maintaining Access Strategy & Type of Access \\
\hline $\begin{array}{l}\text { Conducting deliberations } \\
\text { with FFG Members, } \\
\text { Stakeholders, industry, } \\
\text { retailers and the government }\end{array}$ & $\begin{array}{l}\text { Maintaining close relationships with } \\
\text { retailers and exporters, implementing } \\
\text { the agreements, and also maintaining } \\
\text { forestry land management for coffee } \\
\text { plantations }\end{array}$ & $\begin{array}{l}\text { Technology, } \\
\text { worforce, social } \\
\text { identity, social } \\
\text { relations, and identity }\end{array}$ \\
\hline
\end{tabular}

Access to technology obtained by member farmers is government assistance with complete Arabica coffee processing technology owned by forest farmer groups. These technologies include a complete mini factory, starting with drying machines, pulpers, milling, roasting, drying tanks and modern packaging technology [16]. However, not all farmers have the opportunity to use the technology, as explained by one of the participating farmers:

Post-harvest technology in Karamatwangi Village is still lacking. only a few farmers have post-harvest technology such as pulper machines, doms (drying), and roasting machines. This machine technology assistance was obtained from the government for advanced farmer groups, while for ordinary farmer groups they had not received it. This causes the majority of farmers to sell coffee in the form of logs (cherries).

In addition, the internet access in 2021 can already be used by forest farmer groups to increase market access and strengthen social networks externally. In terms of access to labor, farmers in addition to using forest land to plant coffee and major vegetables, also have an obligation to maintain trees around forest areas so that they remain sustainable, this shows the sustainability of forest management which is more sustainable than before.

The social identity of farmers living around the forest can be said to have the freedom to go in and out of forest areas and tourism, which of course is to access and manage agricultural land in tourist areas and in the Mount Papandayan forest, apart from social relations, each member of the Forest Farmers Group have a good relationship with the management of the Papandayan mountain forest to be able to utilize forest products such as twigs and dead wood for fuel or building materials. The government also allows the 
community to use springs which are professionally managed by the village government through village-owned enterprises, which are responsible for distributing water to the population.

The relationship between farmers and the state as the owner of the forest is a solution relationship, where the government as forest owner also has a need for the presence of the community in managing forests to be more sustainable and involved actively in the early warning system for disasters in forest areas. In addition, the government also needs the community in terms of maintaining security and conservation efforts carried out in the forest. The community plays an active role in supervising foreign parties who commit violations such as logging or other forest destruction that escapes government supervision. Forest rangers are very helpful in carrying out their duties, because in supervising and maintaining forests in order to remain sustainable, it takes a lot of effort, energy, and time, especially considering the large area of the forest area. The role of farmers in collaboration with the local community is an effort to keep the forest sustainable while also improving the welfare of the community. Providing education and discussions with the community regarding the interests of the forest and the interests of living together around the forest are efforts that are implemented in a participatory manner as part of the sustainability of forest management programs with the community.

The situation also encourages farmers, village officials, youth leaders, religious leaders and community leaders to come together to make mutually beneficial agreements and at the same time support forest sustainability. The agreement that occurred, of course, went through a long process and took a long time, because conflicts often arise between the interests of the community and the interests of the government as forest owners. After the agreement, the community becomes responsible for the sustainability and security of the forest area. However, on the one hand, not all farmers in the study area joined the FFG, as stated by the Kramatwangi Village Head :

\begin{abstract}
Most of the farmers in Karamatwangi village actively participate in farmer group activities. however there are some farmers who are not members of farmer groups for various reasons, one of which feels that joining a farmer group is still not important for them and the number of farmer groups in Karamatwangi Village is not proportional to the number of farmers in Karamatwangi village.
\end{abstract}

\title{
3.2 Social networks of forest farmer groups
}

The social network structure describes the flow or goods and information from one farmer to another and from actors outside the system. The social network structure in the marketing activities of FFG Members is more open because the clicks formed by the $\mathrm{s}$ are still exchanging information. $\mathrm{s}$ who socialize between social structures like this are referred to by Rogers and Kincaid [17] as radial personal networks.

Actor Number 1 is the head of the Forest Farmers Group who is also a rich farmer and also a collector trader. This actor is often used as a place to ask other member farmers to discuss and find out related to marketing and prices. This actor plays a major role in distributing marketing-related information to all members of the Forest Farmers Group in the network. Constraints related to marketing in coffee and vegetable farming, this actor is able to solve these obstacles both in terms of capital, marketing and supply of production inputs. In addition, most of the farmers who are members of the Forest Farmers Group also sell their agricultural products to this actor 1. Some farmers agree and said that:

"With the existence of a forest farmer group and the leadership of the chairman, currently the farmer is able to carry out coffee cultivation activities other than 
intercropping with vegetables, and the farmer is able to support their livelihood."

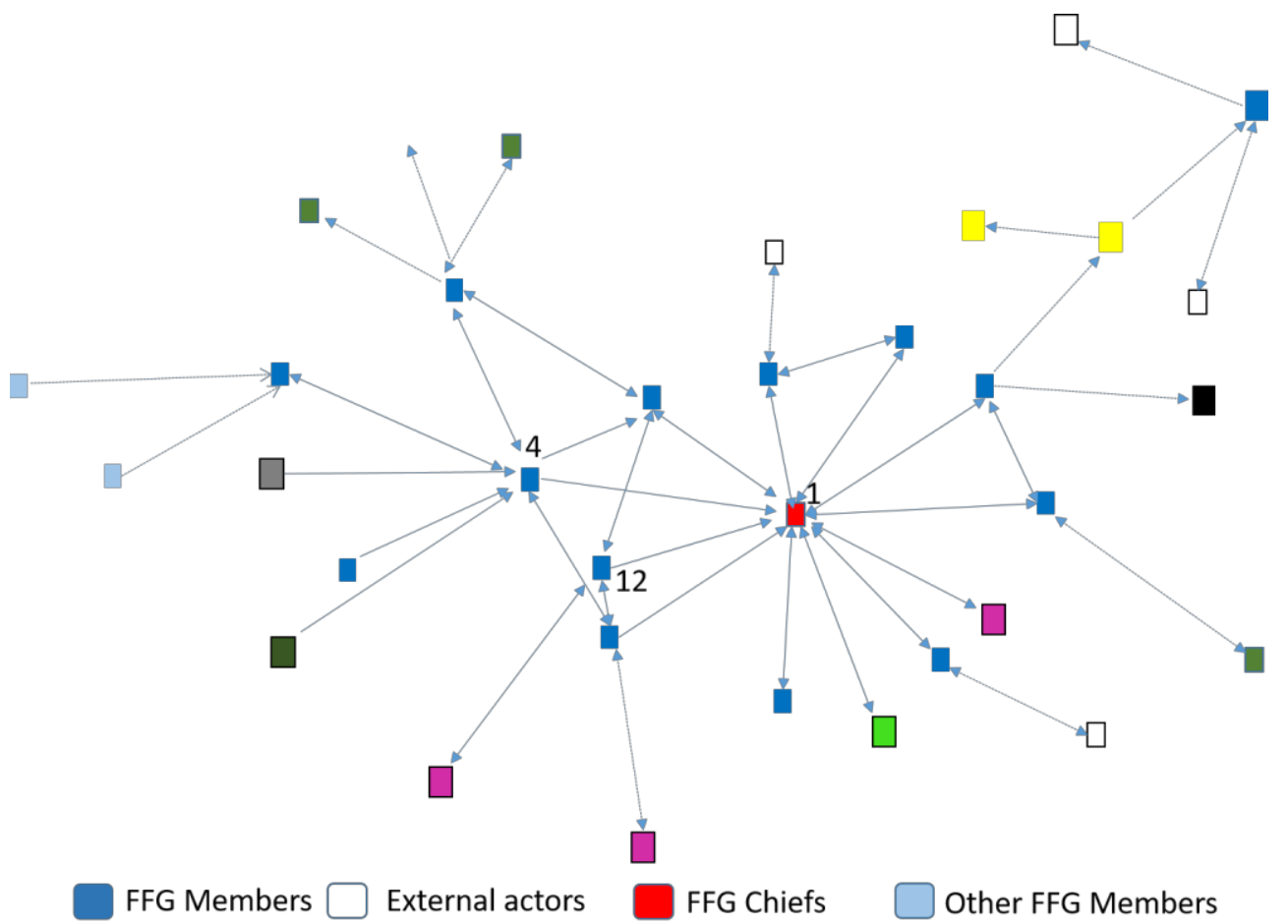

Fig. 2. Social Network structure in acces activities

The collected production results are then combined with other groups in Cisurupan District and then processed in the form of coffee beans that are ready to be sold to major cities, exporters and resellers for the needs of the domestic market and overseas markets. This shows that actor number 1 has the highest level of popularity for the entire agribusiness system of agricultural products, both in terms of marketing, production, postharvest and institutional.

Actor number 4 is a member of the Forest Farmers Group who is also a collector of coffee beans and other agricultural products. The business scale of actor number 4 is bigger than actor number 1 because it is a pioneer who opens up coffee market opportunities for the café and reseller market, due to the wide market network and association. The wide market access causes this actor to often be used as a reference regarding market information, capital and business development. However, this actor 4 respects the leadership of Actor 1 as the head of the forest farmer group and also a community leader. Another advantage of this actor 4 is its openness to market information and price information.

This study also further analyzes the aspects of betweenness centrality and closeness centrality. Betweenness centrality measures the level of an actor as an intermediary from one actor's relationship with other actors in a social network. The results of Pajek's calculation show that the actors who have the highest value of Betweenness Centrality are actor number 1 (value 0.638), actor number 4 (value 0.421 ), and actor number 12 (value 0.310 ). Closeness Centrality analyzes the closeness of actors with all other actors in a social network that is formed formally or informally. The results of the calculation show that the actors who have the highest Closeness Centrality value are actor number 1 (value 0.540), 
actor number 4 (value 0.520), and actor number 12 (value 0.454). Actors number 1 and 4 apart from being leaders of forest farmer group organizations, also play a role and are responsible for the welfare of member farmers. Closeness Centrality values owned by actors number 1 and 4 show a higher level of closeness compared to other actors. While the value of Betweenness Centrality owned by actor number 1 and 4 shows that it is an important liaison actor or intermediary between one actor and another that strengthens bonds between actors both in internal and external networks.

The results show that the current situation of farmers is in the stage of maintaining access through efforts to increase and maintain the type of access to capital, technology, knowledge, market and social relations. This study also shows the form of the Radial Personal Network which shows a form of personal network that is widespread, large, and open to outside information so that it is able to improve the welfare of farmers.

\section{Conclusion}

The conclusions of this research include that forest Farmer Group is in the stage of maintaining access through efforts to increase and maintain the access to capital, technology, knowledge, markets and social relations. Other than that, this study also shows the form of Radial Personal Network which shows a form of spread, large, and open to outside information. It also shows that existing condition is considered to be improved to strengthen responsiveness to access mechanism and strenghtening social networks both domestic and international network.

\section{References}

1. S. Ekawati, K. Budiningsih, Sylviani., Kajian tinjauan kritis pengelolaan hutan di Pulau Jawa. B. Puspijak 9, 1 (2015)

2. C. Kubitzaa, V. Krishnaa, K. Urbanc, Z Alamsyahd, M Qaim. Ecological Economics. 147 (2018).

3. H. Kaskoyo, AJ. Mohammed, M Inoue. JFS. 30, 1 (2014).

4. A. Widiyanto. IJFR. 6, 1 (2019).

5. N. Peluso., \& J. Ribot, Postscript: A Theory of Access Revisited, Society \& Natural Resources. 33, 2 (2020).

6. P. Narh, Land Sector Reforms in Ghana, Kenya and Vietnam: A Comparative Analysis of Their Effectiveness. Land. 58 (2016).

7. V. Krebs, Social Network Analysis, A Brief Introduction. 2009.

8. S. Wasserman, K. Faust K. Social network analysis: Methods and applications. Cambridge University Press (1994).

9. T. Müller-Prothman T, Leveraging Knowledge Communication for Innovation: Framework, Methods and Applications of Social Network Analysis in Research and Development, Wien: Peterlang, (2006).

10. S.A. Awang, Panduan Pemberdayaan Lembaga Masyarakat Desa Hutan (LMDH). Montpellier, France: French Agricultural Research Centre for International Development (CIRAD), Bogor, Indonesia: Center for International Forestry Research (CIFOR), dan Yogyakarta, Indonesia: PKHR Fakultas Kehutanan UGM (2008).

11. E.N. Muange,; Schwarze, Stefan; Qaim, Matin, Social networks and farmer exposure to improved crop varieties in Tanzania, GlobalFood Discussion Papers, No. 45, (2014). 
12. IFAD, Revised Approach Paper Smallholder Access to Markets (SAM) Evaluation Synthesis (2015).

13. M. Magesa, M. Kisangiri $M$ and J. Ko, Access and use of agricultural market information by smallholder farmers: Measuring informational capabilities, EJISDC (2020).

14. L.A. Hoang, J.C. Castella, P. Novosad, Social networks and information access: Implications for agricultural extension in a rice farming community in northern Vietnam, Agriculture and Human Value (2006).

15. H. Markelova, R. Meinzen-Dick, Collective action for smallholder market access. CGIAR (2009).

16. J. Milgroom, K. Giller dan C. Leeuwis, Three Interwooven Dimensions of Natural Resource Use: Quantity, Quality and Access in The Great Limpopo Transfrontier Conservation Area. Human Ecology (2014).

17. J. Napitu, Hidayat dan S. Sjaf. Mekanisme Akses pada Hak Kepemilikan di Kesatuan Pengelolaan Hutan Produksi Meranti Jurnal Penelitian Sosial dan Ekonomi Kehutanan Vol. 14 No.2, 2017 : 101-118 (2017).

18. J. Scott, Social network analysis. Sage Publication (2017).

19. Eriyanto, Analisis Jaringan Komunikasi. Jakarta: Kencana (2014).

20. Tridakusumah et al, IOP Conf. Ser.: Earth Environ. Sci. 771012002 (2021).

21. E.M. Everret, D. L. Kincaid .1981. Communication Networks. Toward a New Paradigm for Reseach. New York: The Free Press. 